\title{
The Relationship between Value Domains and Subjective Well-Being of Employees: Evidence from Turkey $^{1}$
}

\author{
Aytül Ayşe Özdemir \\ Anadolu University
}

Faculty of Economics and Business Administration

aacengiz@anadolu.edu.tr

Doi:10.5296/ ijhrs.v4i4.6384 URL: http://dx.doi.org/10.5296/ ijhrs.v4i4.6384

\begin{abstract}
The main purposes of this study were to examine Turkish employees' value preferences and to explore the relation between the preferences of value domains and subjective well-being. The study conducted on 145 employees working in private organizations indicated that universalism, benevolence, conformity, self-direction is the most strongly endorsed value domains by Turkish employees. It was found that achievement, hedonism and stimulation correlated positively with positive affect. Benevolence and tradition correlated negatively with positive affect. Universalism made a negative; tradition did a positive effect on life satisfaction. Suggestions for future research are explored.
\end{abstract}

Keywords: Value types, Positive affect, Negative affect, Life satisfaction

\footnotetext{
${ }^{1}$ The extended abstract of this study was presented in 2.Organizational Behavior Conference organized by Melikşah University (Kayseri, Turkey), 7-8 November 2014.
} 


\section{Introduction}

The meaning and predictions of well-being has always been a considerable debate issue. One of the perspectives related to well-being labeled as hedonism which perceives happiness vital to optimal positive functioning. Utilitarianism, the modest type of hedonism, holds the view that happiness or subjective well-being can be achieved by maximizing pleasure and minimizing pain. Subjective well-being covers individuals' own judgments of their lives (Diener et al., 2009), and assesses a very broad field of quality of life, such as social relationships, work satisfaction, health etc. (Diener, et al., 2008).

The interest to understand the underlying process of subjective well-being smooth the path for academic research conducted to analyze the predictors of the term. There is a large body of evidence suggesting that personality and socio-economic variables account for a substantial percentage of variance in subjective well-being. On the other hand, values, as an important tool to guide behaviors, are illustrated as predictors of subjective-well-being. Research in varied cultures has demonstrated that pursuing "healthy" values (e.g. benevolence, self-direction, universalism, and achievement) contributes to well-being, whereas pursuing "unhealthy" values (e.g., power, tradition, conformity, and security) harms it (Sagiv \& Schwartz, 2000). Based on a theoretical framework, Self-determination theory imposes that autonomy, relatedness, and competence are basic psychological needs. Giving priority to these intrinsic or growth needs promotes intrinsic satisfaction. In contrary, placing strong importance to extrinsic needs (e.g., fame, public image, power over people, wealth) or deficiency needs are detrimental to well-being (Ryan\&Deci, 2001; Bilsky\&Schwartz, 1994; Kasser\&Ahuvia, 2002; Kasser\&Ryan, 1996; Vansteenkiste et al., 2006). In this vein, it is critical to highlight that literature of well-being is criticized due to its negligence of culture-side effect (see Lu \& Gilmour, 2006). Western definitions of well-being may obscure the potential relationship between values and happiness. To tackle this drawbacks, this study seeks to examine the relationship between Schwarzian value domains and subjective well-being in a sample of Turkey employees. Examining the relationship in Turkish is a challenging case with its western and traditional features. Located at the intersection of the east and west, Turkey holds a mixed culture of individualism and collectivism. Also, the country faces with a rapid social and political change; and to explore the underlying domains of values with a comprehensive outlook can present an insight how the employees' values are affected from the rapid change.sagiv

Draw upon these highlights, the aims of the present study are (1) to investigate basic value dimensions in Turkey, and (2) to examine the direct relationship between ten types of Schwarzian values and both the cognitive and affective aspects of subjective well-being. The contribution of this study can be identified as: This study is the first in extant literature to clarify the underlying dimensions of Schwarzian value domains of Turkish employees. Also, to investigate value domains as predictors of subjective well-being in Turkey makes this research a first step to develop a systematic framework in organizations. 


\section{Schwartz Theory of Basic Values}

Schwartz (1992) defines the concept of values as beliefs or orientations toward life that motivate people to pursue their desirable goals; ordered by relative importance which serve as guiding principles to select or evaluate of actions, people, policies etc.

The values theory represents ten motivationally distinct types of values which are cognitive representations of three universal requirements of human existence: needs of biological organisms, coordinated social interaction, and survival and welfare needs of groups.

Schwartz (1992) further organize the value types along two dimensional bipolar space for individual level analysis. The first bipolar dimension depicts openness to change (self-direction and stimulation) on one pole and conservatism (security, conformity, tradition) on the other. The second opposition depicts self-enhancement (power and achievement) on one pole and self-transendence (universalism and benevolence) on the other. Hedonism is illustrated both to openness to change and self-enhancement. Self-transendence is an orientation toward welfare of others (priority of interests above one's own), whereas self-enhancement is an orientation toward self-interest (priority of self interest).

The values are located on a circumplex according to the rule that conflicting value types are in opposing directions from the center and congruent value types are adjoined to one another. The circular arrangement of the values represents a motivational continuum. The closer any two values in either direction around the circle, the more similar their underlying motivations. The more distant, the more opposite their motivations (Schwartz, 1992). Recent research demonstrated that there is also a strong support for the contention that values are structured in similar ways across cultures (Bilsky et al., 2011; Fontaine et al.,2008).

\section{TurkishCultureand Value Orientations}

It is really important and challenging to examine the values of Turkish employees. Because there is no unique, typical Turkish society value set. Turkish societal culture and hence organizational culture is a mixture of traditional and modern values. Historical context analysis beginning from late 17th century sign that Ottoman lands were mostly seized by Western powers after the WWI. Turkey fought a war of independence, recovered some lands, and also searched for the transferability of military technology know-how and management/organization experience that the Western countries possessed. The time of Westernization constitutes the history of the response to the challenge in military, political, economic and cultural realms. Ottoman Empire, which has been regarded as its weak civil society and patrimonial state tradition, conveyed a value system which is still centralized and autocratic. Subsequent to abolishment of Ottoman Empire, the Turkish Republic was founded in 1923, outstanding with a secular democratic state which has a predominantly Muslim population (Esmer, 2008; Bolak-Boratav, 2009; Arbak, 2005; Hortaçsu\&Cem-Ersoy, 2005; Berkman\&Özen, 2008).

In line with a rapid social, political, economic, cultural development has not create the same effect in every part of society. As Mardin (1973) mentioned, center-periphery cleavage has begun to occur in Turkish society. Undergoing rapid social and economic changes in line with 
the principles of nationalism, secularism, republicanism, populism, reformism and etatism, Turkey has been going through a dense conflict between the center which has been represented by ruling elite groups (civil and military bureaucratic groups) and the periphery represented by various social groups such as the emerging middle class, the rural upper class, artisans and religious groups etc. (Berkman\&Özen, 2008). Despite urbanization and relatively recent adaptation of a market-led economic policy, this divide remains deep (Çarkoğlu, 2012). As a consequence of this deep division, social capital of Turkey and generalized level of trust in society significantly remains in a low level (Esmer, 2008; Sargut, 2003)

Under the effect of worldwide liberalization and globalization movements, especially the presidential period of TurgutÖzalin 1980's, Turkish economy has made a peak in liberalization (Öniş, 2004) and become more integrated with the world capitalist system (Berkman\&Özen, 2008). But we also have to mention that liberalization experience during 1980's has not significantly changed the distinguishing characteristics of its state-dependent nature of business system and family-controlled business groups. (Berkman\&Özen, 2008). However, there were also some changes going through more individualistic values perceived in economic enterprises and in society. Recent studies in management culture mentioned that prevalent management culture has gradually become less collectivistic, high in uncertainty avoidance, and paternalistic (Aycan, 2006; Arslan, 2001; Kabasakal\&Bodur, 2002), and have an entrepreneurial organizational culture rather than hierarchical or clan culture (Ateş, 2004).

A dual culture embodying both modern and traditional values in a context of liberalism oriented socio/economic change of 1980's has surfaced itself in a comprehensive academic research. According to Arbak (2005), people living in Coastal Towns and living in Inland Towns are distinctly different from each other. Costal Town people who were exposed to different cultures are also flexible, open to change. On the other hand, Inland Town people are dependent, militarist, religious, centralized, patrimonial and traditionalist-conventionalist. According to Aygün and İmamoğlu (2002), their study conducted among Turkish university students and adults concluded that both individual and group related concerns were preferred by Turkish people. First universalism, second benevolence domain has gained importance. The third value domain was self-enhancement which included social power, recognition and achievement. This study illustrated that in Turkey, increasing education and urbanization, people tend to have strong inclination towards individuation and autonomy with a significant decline in conservative values of tradition-religiousness and normative patterning.

The year of 2002 is a critical time that conservatism with a notion of religiousness preferences has come to increase. The party which is established by pro-Islamic leaders, named as Justice and Development Party (Adaletve Kalkınma Partisi-AKP), swept into power in the general elections of 2002 and received 34 percent of votes. The party ruined Turkish society maintain with Islamic discourse in social field and political program. Under these circumstances, Turkish society has got a more deep division and social polarization within the more inclination towards conservatism and religiousness. One of the recent studies pointed out that religion is the primary factor shaping Turks' national identity. Despite the country's elite's global aspirations, ordinary citizens have remained parochial (Hurriyet Daily 
News, 2014). Another study examined changing values based on World Values Survey indicated that rising religiosity and intolerance have become more visible during the AKP's ruling (Yeşilada \& Noordijk, 2010). Religiosity is positively associated with conservative values (Çukur et al., 2004; ) and in Turkey religion is the most important value restricting social interaction with the others who do not believe in God or do not Muslim, and also increasing intolerance (Esmer, 2009; Topraket al., 2006). AKP experience in Turkey has lead a conservative value domain which results in widening of political, cultural, societal polarization (Keyman, 2010). Under this context, one of the research conducted among Canadian and Turkish university students has revealed that Turkish sample scored higher on tradition, benevolence, universalism, self-direction and security than their Canadian counterparts (Clevaland et al., 2011). Highly consistent with this finding, Dirilen-Gümüş \& Büyükşahin-Sunal (2012) have emerged that benevolence, self-direction, universalism, security and hedonism were strongly endorsed by Turkish university students. Given these results, it seems that a reflection of both individuation and conservatism tendency can be surfaced under a rapid transformation context.

When the turn comes to examine the values in organizations, Turkish organizations are remarked as collectivist, paternalistic, hierarchical and high in power distance (Fikret-Paşa et al., 2001; Aycan et al., 2000). Although the process of globalization and modern industrialization, have pave the way for convergence of values among societies, still socio-cultural values greatly influence management styles and values of organizational members. (Berkman\&Özen, 2008). In accordance with this finding, the study of Arbak conducted in 1997 indicated an overall picture of how public and private organizations different from each other. Public sector organizations seem to be against change, clumsy and very bureaucratic, whereas private organizations seem to be more dynamic and open to change. Extended research have shown that Turkish work values include both "western" and "culture-specific" values. Integrity, hardworking and achievement are the most preferred values (Aldemir et al., 2003; Arslan, 2001a; Örücü et al.,2003; Aygün et al., 2008; Aşkun et al., 2010). One study examined the potential managerial values differences among managers and MBA students found that both groups placed a higher importance to security, self-direction and low importance to stimulation and power. Tradition was tended to devalue and achievement was tended to valued higher than managers by MBA students (Çakmakçı\&Karabatı, 2008).

Based on these findings, the examination of Turkish employee's value preferences is a promising way to gain insights into the nature of transformation process characterized with social polarization in social life, and characterized with liberal policies exist with conservative attitudes in economic domain. Thus, in this study we investigated basic value dimensions of employees in Turkey. In general, we expected our Turkish respondents to value both self-transcendence values as well as individualistic values. Grounded on this knowledge, the first research question of this study is organized as follows:

RQ1: Whichdomains of values are endorsed by Turkish employees? 


\section{Subjective Well-Being}

Subjective well-being (SWB), a core concept of positive psychology, place a great importance on current literature focused on well-being and happiness research. Apart from subjective well-being which holds hedonic oriented position, psychological well-being is associated with eudemonic position which deals with human potential (virtues, skills) and personal growth (Ryff\&Singer, 1998; Keyes\&Annas, 2009). On the other side, hedonic oriented psychological position holds that well-being is conceived as identical to subjective well-being which is assessed as experiencing pleasant emotions, low levels of negative moods and high life satisfaction (Diener et al., 2009). Affective components of SWB are positive affectivity (PA) and negative affectivity (NA), whereas cognitive-judgmental aspect of SWB is life satisfaction (Diener, 1984; Myers\&Diener, 1995).

Positive affectivity (PA) reflects the degree to which a person experiences feelings such as enthusiasm, active, and alert. High levels of PA is a state of high energy, full concentration and pleasurable engagement with the environment. While low levels of PAis a reflection of sadness and a lack of vitality. Negative affectivity (NA) refers to a general dimension of subjective distress and unpleasable engagement, and is identified by aversive mood states such as anger, contempt, disgust, fear, and nervousness. Low NA is a state of being calmness and relaxation(Watsonet al., 1988). PA and NA seems to be opposite, but these two components are represented as orthogonal dimensions rather than bipolar (Chan, 2001).

Life satisfaction has been operationalized and assessed as an internal judgment based on a self-chosen standards to evaluate of actual life circumstances with ideal ones (Diener et al., 2009). The ideal life, or satisfying life is a reflection of personal evaluation rather than externally imposed thought (Diener, 1984).

"What makes people happy?" is the most examined question in positive psychology. When people calculate a life satisfaction judgment, the findings have arrived at a more complete understanding of the profound differences between individualistic and collectivist cultures (Diener et al., 2009; Suh et al., 2008; Suh et al., 1998; Aygün\&İmamoğlu, 2002). In Turkish population, characterized as both collectivist and individualistic, basic needs fulfillment (Doğan\&Ery1lmaz, 2012), self-esteem (Eryılmaz\&Atak, 2011), hope and forgiveness (Yalçın\&Malkoç, 2014), attachment style (Öztürk\&Mutlu, 2010), parenting style (Demirutku, 2007) can be summarized as predictions of subjective well-being. Both personality factors (e.g., extroversion,locus of control) and environmental factors (e.g., social support)can shape the calculation of subjective well-being (see Gallagher\&Vella-Brodrick, 2008).

When there is a need to derive a comprehensive understanding to the process of SWB, there is a substantial tool, which is value orientations. Several theorists argued that value orientations are associated with SWB. According to Oishi et al. (1999), value orientations play the role of moderator between domain satisfaction and global life satisfaction. In line with this approach, satisfaction domains affect SWB most strongly when they are congruent with one's value orientations. For example, individuals who prefer benevolence values are more satisfied when dealing with activities related to social life, whereas individuals who prefer conformity values are more satisfied when dealing with activities related to family ties 
(Oishi et al., 1999).Grounded in self-determination theory (Deci\&Ryan, 2000), the other approach signs a direct relationship between values and SWB, posit that intrinsic goals such as personal growth, autonomy, satisfying relationships, and community contribution are more related to sense of satisfaction than activities related to extrinsic needs such as financial success, public image, social recognition, control over others, and physical attractiveness (Kasser\&Ryan, 1993; Kasser\&Ahuvia, 2002, Ryan et al.,1996). Sagiv\& Schwartz (2000) found that stimulation, self-direction, and achievement were correlated positively with positive affect. Security, conformity, and tradition were correlated negatively with positive affect. Consistent with this finding, Roccas et al.(2002) demonstrated that self-direction, stimulation, and universalism were positively associated with positive affect, whereas conservatism and power were negatively associated. Similarly, another study pointed out that achievement, hedonism, stimulation, self-direction, universalism, and benevolence lead to higher positive affectivity. Besides stimulation, self-direction, universalism, and benevolence are more strongly related with subjective sense of well-being (Haslamet al., 2009). It should be noted, however, value priorities of individuals presumably affect which activities are more strongly related to progress in SWB.

Although values and SWB are conceptually distinct, they are empirically related. If the values are account for some of the predictive variance associated with $\mathrm{SWB}$, it can be worthwhile to assess the contribution of values to SWB on Turkish employees where the social/economic context embody both individualistic and conservative features. On this basis, this present study aimed to examine the relation between the preferences of value domains and subjective well-being. Regarding this aim, the second research question can be constructed as follows:

RQ2: Which domains of values are more strongly associated with subjective well-being?

\section{Method}

\subsection{Respondents}

The study was conducted on two different private organization, located in Eskişehircity (Turkey). One of the organization operates in aviation, and the other does in technology sector.The response rate was 72 percent. A total of 145 questionnaire form was used after eliminating incomplete forms. The mean age of employees 32.21 years $(\mathrm{SD}=1.51)$. Education of employees ranged from 1 (high school) to 4 (master's degree) with a mean of 3.54 $(\mathrm{SD}=1.72)$. The mean of employee tenure was 5.67 years $(\mathrm{SD}=1.84)$.

\section{2. $\quad$ Measures}

Participants completed a questionnaire form containing three scales with demographic information.

Portrait Values Questionnaire (PVQ): Schwartz's Portrait Values Questionnaire (Schwartz et $a l ., 2001$ ) measures the ten individual values (Universalism, Benevolence, Security, Tradition, Conformity, Self-Direction, Power, Hedonism, Stimulation, Achievement). The scale comprises 40 items, with participants were asked to assess how similar they are to the 
portrayed individual on a6-point scale (from 'very much like me' to 'not at all like me'). A typical item was "It's very important to him/her to be rich. He/She wants a lot of money and expensive things".

Turkish adaptation of PVQ was conducted by Demirutku\&Sümer (2010), and the following test-retest reliabilities were obtained: Universalism (0.72), Benevolence (0.66), Security (0.80), Tradition (0.82), Conformity (0.75), Self-Direction (0.65), Power (0.81), Hedonism (0.77), Stimulation (0.70), Achievement (0.81). In this study, internal reliabilities for the value types were: Universalism (0.68), Benevolence (0.54), Security (0.60), Tradition (0.48), Conformity (0.64), Self-Direction (0.56), Power (0.46), Hedonism (0.80), Stimulation (0.72), Achievement (0.79).PVQ has been widely used in Turkey to measure values. These low reliabilities can be grounded to small number of items used to measure each value. Internal reliabilities were similar to several past studies (see for example Bolak, 2005; Dirilen-Gümüş, 2009).

Positive Affectivity, Negative Affectivity Scale(PANAS):PANAS (Watson et al., 1988) measures dispositional affect. Participants were asked to indicate how often they generally experience ten positive (e.g., joy, enthusiasm, active) and ten negative emotions (e.g., quilt, depression, anxiety, hostility), rated from very slightly or not at all (1) to extremely (2).Turkish adaptation of PANAS was conducted by Gençöz (2000) and both scales had a satisfactory internal consistency $(\mathrm{PA}=0.86, \mathrm{NA}=0.83)$. In this study, internal reliabilities for PA was 0.82 , for NA was 0.77 .

Satisfaction with Life Scale (SWLS): SWLS (Diener et al., 1985) measures global life satisfaction, with five item, such as "If I could live my life over, I would change almost nothing." Participants were instructed to indicate their level of agreement with each statements on a five point scale ranging from strongly disagree (1) to strongly agree (5).Turkish adaptation of SWLS was conducted by Köker (1991) and Yetim (1993). The corresponding reliabilities for each study was 0.78 and 0.86 . For this study, internal reliability was 0.88 .

Correlations of the positive affect scale with the negative affect scale was $r=-17(\mathrm{p}<.05)$. Correlation of the positive affect scale with the life satisfaction scale was $r=.23(\mathrm{p}<.01)$, and correlation of the negative affect scale with the life satisfaction scale was $r=-15(\mathrm{p}<.05)$. The low size of these correlations is consistent with the current view in the well-being literature that the cognitive and affective aspects of subjective well-being are distinct and their indexes should be treated separate.

\subsection{Procedure}

Employees completed the surveys at their convenience and during regular working hours. The survey was endorsed by Human Management Department of the organizations. The completion of questionnaires took 25-30 minutes. Their answers kept anonymously.

\subsection{Results}

Table 1 demonstrates that there was a significant difference in the scores for 
self-transendence $(\mathrm{M}=5.00, \mathrm{SD}=.50720)$ and self-enhancement $(\mathrm{M}=4.01, \mathrm{SD}=.85490)$; $\mathrm{t}(144)=13.131, \mathrm{p}<.05)$. Also, there was no significant difference in the scores for conservatism and openness to change; $\mathrm{t}(144)=3.422, \mathrm{p}>.05$.

Our sample placed more importance on values of universalism $(\mathrm{M}=5.07, \mathrm{SD}=.57991)$, security $(\mathrm{M}=4.99, \mathrm{SD}=.61598)$, benevolence $(\mathrm{M}=4.93, \mathrm{SD}=.57435)$, self-direction $(\mathrm{M}$ $=4.85, \mathrm{M}=.62590)$, and conformity $(\mathrm{M}=4.83, \mathrm{M}=.70969)$. On the other hand, power $(\mathrm{M}$ $=3.75, \mathrm{SD}=.90845)$, stimulation $(\mathrm{M}=4.03, \mathrm{SD}=.99793)$, tradition $(\mathrm{M}=4.05, \mathrm{SD}=.79521)$, hedonism $(\mathrm{M}=4.23, \mathrm{SD}=1.1284)$ and achievement $(\mathrm{M}=4.28, \mathrm{SD}=.97071)$ were the least preferred value types by the sample.

Table 1: Mean and Standard Deviation of Variables

\begin{tabular}{|c|c|c|}
\hline Variables & Mean & Standard Deviation \\
\hline Power & 3.75 & .90845 \\
\hline Achievement & 4.28 & .97071 \\
\hline Hedonism & 4.23 & 1.12842 \\
\hline Stimulation & 4.03 & .99793 \\
\hline Self-direction & 4.85 & .62590 \\
\hline Universalism & 5.07 & .57991 \\
\hline Benevolence & 4.93 & .57435 \\
\hline Tradition & 4.05 & .79521 \\
\hline Conformity & 4.83 & .70969 \\
\hline Security & 4.99 & .61598 \\
\hline Self-transendence & 5.00 & .50720 \\
\hline Self-enhancement & 4.01 & .85490 \\
\hline Conservatism & 4.63 & .56960 \\
\hline Opennesstochange & 4.37 & .72963 \\
\hline
\end{tabular}




\section{Macrothink}

Table 2 presents the correlations of the ten value types with three indexes of subjective well-being in the sample. As Schwartz mentioned (1992, p.53), in order to focus on the consistent and reliable findings, individuals' ratings of each value around their own mean are standardized (based on $\mathrm{r}$ to $\mathrm{Z}$ transformation). As a result of this standardizing, to avoid the potential change that can be seen in the pattern of intercorrelations among values, each individual's mean rating for ten value types were added as a control variable through partial correlation.

As can be seen from Table 2, achievement $(r=.14$, p < 0.05), hedonism $(r=.16, \mathrm{p}<0.05)$ and, stimulation $(r=.24, \mathrm{p}<0.01)$ correlated positively with positive affect. Benevolence $(r=$ $-.18, \mathrm{p}<0.05)$ and tradition $(r=-.23, \mathrm{p}<0.01)$ correlated negatively with positive affect. None of the value types correlated significantly with the negative affect, except benevolence $(r=-.15, \mathrm{p}<0.05)$. Universalism $(r=-.16, \mathrm{p}<0.05)$ correlated negatively, and tradition $(r=.18, \mathrm{p}<0.05)$ correlated positively with life satisfaction.

Table 2: Correlations of Value Types with Indexes of $\mathrm{SWB}^{\mathrm{a}}$

\begin{tabular}{|llll|}
\hline Value Types & PA & NA & SWL \\
\hline Power & .11 & -.01 & -.04 \\
Achievement &. $\mathbf{1 4} *$ & .09 & -.05 \\
Hedonism &. $\mathbf{1 6 *}$ & .02 & -.01 \\
Stimulation &. $\mathbf{2 4} * *$ & -.09 & -.07 \\
Self-direction & .12 & .09 & -.01 \\
Universalism & -.13 & -.10 & $\mathbf{- . 1 6 *}$ \\
Benevolence & $\mathbf{- . 1 8 *}$ & $\mathbf{- . 1 5 *}$ & .01 \\
Tradition & $\mathbf{- . 2 3 * *}$ & .14 & .12 \\
Conformity & -.13 & -.09 & .02 \\
Security & -.13 & -.02 & .12 \\
\hline
\end{tabular}

Note: $P A=$ PositiveAffectScale $; N A=$ NegativeAffectScale $; S W L=$ Satisfaction -with Life Scale

${ }^{a}$ Correlations are partialed on each respondent's mean ratings of all values to correct for scale use, as recommended in Schwartz (1992). 
$* \mathrm{p}<0.05, * * \mathrm{p}<0.01$, one-tailed.

\section{Discussion}

As it is a compromising point that it is vital to examine the validity of theories and assumptions predominantly developed in Western related literature, this study is based on Turkish employees working in private organizations. The main purposes of this study were to examine Turkish employee's value preferences and to explore the relation between the preferences of value domains and subjective well-being.

In conformity with the other studies (Bolak-Boratav, 2009; Kuşdil \& Kağıtçıbaşı, 2000), this study revealed that self-transcendence values were highly valued than self-enhancement values. And there was no statistically significant difference between conservatism and openness to change.

In the present sample, Turkish employees valued universalism as the most important one. Earlier studies conducted on Turkey indicated the same finding in this study (e.g., Aygün \& İmamoğlu, 2002; Bolak-Boratav, 2009; Kuşdil \& Kağıtçıbaşı, 2000; Dirilen-Gümüş \& Büyükşahin-Sunal, 2012). The features of universalism can be summarized as social justice, equality, protection the welfare of the other people. Turkish organizations are characterized as power distant and hierarchical. Power distance can cause unequal, autocracy dominated relationships. The employees' perception of this kind of organizational culture would lead them to favor and highlight universalism values. Because as Schwartz (1992) mentioned universalism values can be surfaced when people face with the problems and realize that something were wrong and have to be changed. One of the outstanding feature of universalism is protecting for the nature. In a recent research, in consistent with this study's finding, Turkish university students have a preference to dominate his/her own money in order to fight environmental pollution, and support nature. Also, according to Atlas of European Values (2008), eighty five present of Turkish society stated that it is important for them to have a job which has beneficial outcomes for society. These findings provide support for the increased importance of universalism.

Secondly, security, and thirdly benevolence are highly valued by Turkish employees. This finding is congruent with those of other studies conducted on Turkish society (e.g.,Kuşdil \& Kağıtçıbaş1, 2000; Dirilen-Gümüş \& Büyükşahin-Sunal, 2012; Aygün \& İmamoğlu, 2002;). Supporting this finding pointing to high preference for security, Kağıtçıbaşı (2005) argued that emotional-psychological commitment is still a need across generations in Turkish type of family. Family is seen as a mechanism that provide protection and emotional support. In line with this finding, according to Atlas Project (2008), the eighty-seven percentage of Turkish individuals who believe that parents have to sacrifice for their children, even it is harmful for them. Besides, loyalty to family is still emphasized in socialization values. Greater emphasis on benevolence has resulted from the fact that Turkish society is characterized as a collectivist country. As Çukur et al., (2004) and Dirilen-Gümüş (2009) mentioned, benevolence appeared to be the core value of collectivism in Turkey. Individuals in Turkey have identified their identity according to their in-group membership and social roles. Within a network of close bonds with family/groups, maintaining harmony and social order is 
important (İmamoğlu\&Karakitapoğlu-Aygün, 2004). Under this circumstances, it is expected that conformity ranked fourth in this sample. These values, such as security, conformity are inherited by Ottoman Empire, and transferred to new generations by parenting style in Turkey. Conventional child-rearing practices emphasize politeness, obedience, loyalty and respect towards parents and elders (Kağıtçıbaşı, 2013; Sunar\&Okman-Fişek, 2005).Behavior in congruent with social norms and expectations of in -group members are a need to protect familial and kinship ties. As a result of this point, respect for authority, obedience and maintaining harmony are also dominant and valued in Turkish organizations.

However, for the sample in this study, conformity was equally endorsed with self-direction. Being creative, choosing own goals are the indicators of self-direction, and characterized as an individualistic value type. Young and educated individuals prefer freedom and authenticity as a reflection of a tendency being more individualistic. In relation to this, Bolak-Boratav (2009), Başaran (1992) and Dirilen-Gümüş\&Büyükşahin-Sunal, (2012) indicated the same finding in their studies. Another point in this finding may be related with the features of occupations and organizations. Most of the sample in this study is engineer, working in private organizations. These kind of occupations needs to be creative, innovative. As it was mentioned before, organizational culture in private ones are more inclined to openness to change and less hierarchical in Turkey.

The second purpose of this study is to explore the underlying relationship between value domains and both the affective/cognitive aspects of subjective well-being. The findings of correlation analysis highlighted that benevolence value type has a negative correlation with both positive and negative affectivity. Drawing on humanistic perspective, it was expected a negative relation between benevolence and negative affectivity. Benevolence, as expressing intrinsic motives, supply the need of relatedness. (Bilsky\& Schwartz, 1994). Caring the needs of other people, being helpful and kindness may lead to decrease in negative moods and emotions. However, in this sample, the finding pointing out a negative correlation with benevolence and positive affectivity isnot strictly in line with the other studies (see Sagiv\&Schwarzt, 2000). One possible explanation for this finding can be the low degrees of social capital and trust in Turkey. As evidenced in this study, Turkish people believe that benevolence is important and being benevolent decrease their negative emotions such as anxiety or anger. However, the potential conflict and discrimination between in-group and out-group can diminish perception of benevolence and generate distrust for out-group members (see Williams, 2001).As Sargut(2001) pointed out that vertical collectivism in Turkey leads to decrease in social capital and diminish societal synergy under the effect of group-level conflict. Similarly, some line of research argued that value types that represent growth needs (e.g., benevolence) relates positively to well-being when related goals are reached (Bilsky\&Schwarzt, 1994). If people cannot meet their need of emotional intimacy and social support, this could generate a negative effect on positive affect.

Another finding in this study is the positive correlation between the values of achievement, hedonism and stimulation, and positive affectivity. This finding is consistent with the other studies based on self-determination theory (Ryan et al., 1996; Vansteenkiste et al., 2006). The pursuit of intrinsic needs or goals benefits people's well-being, and lead to feel more positive 
emotions or moods.

The other value type, which correlated negatively with positive affectivity is tradition. Tradition was one of the least preferred value types, and one of the two value types that have an effect on cognitive aspect of subjective well-being in this sample. The decrease in importance for tradition is expected and understandable with respect to socioeconomic development change in Turkey. However, the interesting one is the positive relationship between tradition and life satisfaction. Turkish society is characterized by high uncertainty avoidance and low risk tolerance. People may cope with uncertainties in their life by showing respect to rules and customs. Tradition is related to religion, and an important line of research indicates a positive relationship between life satisfaction and religion. On the other hand, respect to rules and customs leads to decrease in positive affectivity may have resulted from the fact of conflicting goals. In daily life or in organizational life, the dominant feeling of being humble and moderate may conflict with the goals important to them. The experience of inability to reach important goals may hinder positive feelings (Emmons \& King, 1998). This explanation could be verified by the study of Aygün\&İmamoğlu (2002). They argued that Turkish people tend to prefer tradition with a tendency to questioning its efficiency. Unless traditional values are functional, they lose their strength. The other value type that associated negatively with life satisfaction is universalism. As it was mentioned before, value type that has the highest meaning rate in this sample is universalism. The reason of the negative effect can be explained under the frames of unmet expectations of individuals.

In sum, there was a support for direct, but weak relationships between affective aspects of well-being and cognitive aspects of well-being.

Hence, the findings of this study generally seems to congruent with the other findings that, achievement, stimulation hedonism are the ones that create a positive effect on SWB. What is interesting and different from other studies is the negative effect of universalism, and positive effect of tradition on life satisfaction.

\section{Limitations and Future Studies}

Although the findings of this study help to assure an extensive evidence on the relationship between value domains and cognitive/affective aspects of subjective well-being, the limitations of this study have to be taken into consideration. First, the model in this study do no entail causal and/or indirect relationship between value preferences and subjective well-being. To examine the relationship in more detail with comprehensive outlook, it seems advisable to include measurements of eudemonic well-being. Eudemonic perspective of well-being might be associated more strongly with value domains.

By focusing on employees' value orientations, this study expanded research on values and well-being. But longitudinal cross-sectional design would permit to analyze the development processes and how vary in different demographic variables.

Thus, it seems a challenge for future research to shed more light on the relationship between value domains and subjective well-being in Turkish society and organizations. 


\section{Macrothink}

\section{References}

Aldemir, M. C.,Arbak Y., \&Özmen, N.T. (2003).Türkiye'deişgörmeanlayış1, tanımıveboyutları. YönetimAraştırmalarıDergisi,3 (1), 5-28.

Arbak, Y, (2005). Dominant values of Turkishorganizations: A contradictoryphenomenon.Review of Social,Economicand Business Studies,EasternMediterraneanUniversity, 5 (6), 69-88.

Arslan, M. (2001a). 'The work ethic values of Protestant British, Catholic Irish and Muslim Turkish managers. Journal of Business Ethics, 31(4), 321-339.

Arslan, M. (2001). A cross-cultural comparison of achievement and power orientation as leadership dimensions in three European countries: Britain, Ireland and Turkey. Business Ethics: A European Review, 10 (4), 340-345.

Aşkun, D., Öz, E.U., \&Aşkun, O.B. (2009). Understanding managerial work values in Turkey. Journal of Business Ethics, 93(1), 103-114.

Ateş, H. (2004). Management as an agent of cultural change in the Turkish public sector. Journal of Public Administration Research and Theory, 14 (1), 33-58.

Atlas, European Values Survey, http://www.atlasofeuropeanvalues.eu/new/home.php?lang=en (02.09.2014).

Aycan, Z., Kanungo, R., Mendonca, M., Yu, K., Deller, J., Stahl, G., \&Kurshid, A. (2000). Impact of culture on human resource management practices: A 10-country comparison. Applied Psychology, 49 (1), 192-221.

Aycan, Z. (2006). Paternalism: Towards conceptual refinement and operationalization. In K. S. Yang, K. K. Hwang, \& U. Kim (Eds.), Indigenous and cultural psychology: Understanding people in context (pp. 445-466). New York, NY: Springer.

Aygün, Z. K., \&Imamoĝlu, E. O. (2002). Value domains of Turkish adults and university students. The Journal of Social Psychology, 142(3), 333-351.

Aygün, Z. K., Arslan, M., \&Güney, S. (2008). Work values of Turkish and American university students. Journal of Business Ethics, 80 (2), 205-223.

Başaran, F. (1992). The university students' value preferences. Ankara ÜniversitesiDilveTarihCoğrafyaFakültesiAraştırmaDergisi, 14, 13-25.

Berkman, Ü.,\&Özen, Ş. (2007). Turkish business system and managerial culture: State-dependency and paternalism in transition. Gestion en Contexte Intercultural: Approaches, Problematiques, PratiquesetPlongees. Quebec: Presse de 1'Universite Laval et TELUQ/UQAM, 1-25.

Bilsky, W., \& Schwartz, S. H. (1994). Values and personality. European Journal of Personality, 8 (3), 163-181.

Bilsky, W., Janik, M., \& Schwartz, S. H. (2011). The structural organization of human values 
- Evidence from three rounds of the European Social Survey (ESS). Journal of Cross-Cultural Psychology,42 (5), 759-776.

Biswas-Diener, R., Kashdan, T. B., \& King, L. A. (2009). Two traditions of happiness research, not two distinct types of happiness. The Journal of Positive Psychology, 4 (3), 208-211.

Bolak-Boratav, H. (2009). Values and attitudes of young people in urban Turkey: Further test of Schwartz'theory of values and Kağıtçıbaşı's model of family change. In Cultural perspectives on human development: Essays in honor of ÇiğdemKağıtçıbaşı, (pp.263-283).

Çakmakçı, U. M., \&Karabatı, S. (2008). Exploring managerial values in the changing Turkish business context. Journal of Management Development, 27(7), 693-707.

Çarkoğlu, A. (2012). Economic evaluations vs. ideology: Diagnosing the sources of electoral change in Turkey, 2002-2011. Electoral Studies, 31 (3), 513-521.

Chan, D. (2001). Method effects of positive affectivity, negative affectivity, and impression management in self-reports of work attitudes. Human Performance, 14 (1), 77-96.

Cleveland, M., Erdoğan, S., Arıkan, G., \&Poyraz, T. (2011). Cosmopolitanism, individual-level values and cultural-level values: A cross-cultural study. Journal of Business Research, 64(9), 934-943.

Çukur, C. S., De Guzman, M. R. T., \&Carlo, G. (2004). Religiosity, values, and horizontal and vertical individualism-collectivism: A study of Turkey, the United States, and the Philippines. The Journal of Social Psychology, 144(6), 613-634.

Deci, E. L., \& Ryan, R. M. (2000). The" what" and" why" of goal pursuits: Human needs and the self-determination of behavior. Psychological Inquiry, 11 (4), 227-268.

Demirutku, K. (2007). Parenting styles, internalization of values, and the self-concept. (Doctoral dissertation, Middle East Technical University, Turkey.

Demirutku, K., \& Sumer, N. (2010). Temeldeğerlerinölçümü: PortreDeğerleranketininTürkçeuyarlaması [Measurement of basic values: Turkish adaptation of portrait values questionnaire]. TürkPsikolojiYazıları, 25, 17-25.

Diener, E. (1984). Subjective well-being. Psychological Bulletin,95, 542-575

Diener, E., Kesebir, P., \& Lucas, R. (2008). Benefits of accounts of well-being-For societies and for psychological science. Applied Psychology, 57 (1), 37-53.

Diener, E., Lucas, R.E., \&Oishi, S. (2009). Subjective well-being: The science of happiness and life satisfaction. Oxford Handbook of Positive Psychology, UK: Oxford Publications, 63-73.

Dirilen-Gümüs, Ö.,\&Büyüksahin-Sunal, A. (2012). Gender differences in Turkish undergraduate students' values. Sex Roles, 67 (9-10), 559-570.

Dirilen-Gümüş, O. (2009). The relationships between culture, values, personality and 
political ideology: A cross-cultural comparison (Turkey-USA). Unpublished PhD Dissertation. Ankara University, Ankara.

Doğan, $\quad$ T., \&Eryilmaz, $\quad$ A. Akademisyenlerdeişleilgilitemelihtiyaçdoyumuveözneliyioluş. Ege Academic Review, 12(3), 383-389.

Eryilmaz, A., \&Atak, H. (2011). Investigation of Starting Romantic Intimacy in Emerging Adulthood in Terms of Self-Esteem, Gender and Gender Roles.Educational Sciences: Theory and Practice, 11(2), 595-600.

Esmer, Y. (2008). Islam, gender, democracy and values: The case of Turkey, 1990-2001. In T. Pettersson\& Y. R. Esmer (Eds.), Changing values, persisting cultures: Case studies in value change (pp. 275-301), Leiden: Brill.

Esmer, Y. (2009). “RadikalizmveAşırıcılık, Milliyet (Turkish daily), May 31.

FikretPaşa, S., Kabasakal, H., \&Bodur, M. (2001). Society, organisations, and leadership in Turkey. Applied Psychology, 50(4), 559-589.

Fontaine, J. R., Poortinga, Y. H., Delbeke, L., \& Schwartz, S. H. (2008). Structural equivalence of the values domain across cultures distinguishing sampling fluctuations from meaningful variation. Journal of Cross-Cultural Psychology, 39 (4), 345-365.

Gallagher, E. N., \&Vella-Brodrick, D. A. (2008). Social support and emotional intelligence as predictors of subjective well-being. Personality and Individual Differences, 44(7), 1551-1561.

Haslam, N., Whelan, J., \& Bastian, B. (2009). Big Five traits mediate associations between values and subjective well-being. Personality and Individual Differences, 46 (1), 40-42.

Hortaçsu, N., \&Cem-Ersoy, N. (2005). Values, identities and social constructions of the European Union among Turkish university youth. European Journal of Social Psychology, 35 (1), 107-121.

Imamoğlu, E.O., \&Karakitapoğlu-Aygün, Z. (1999). 1970'lerden 1990'laradeğerler: Üniversitedüzeyindegözlenenzaman, kuşakvecinsiyetfarkl1lıkları. TürkPsikolojiDergisi, 14 (44), 1-22.

Kabasakal, H., \&Bodur, M. (2002). Arabic cluster: A bridge between East and West. Journal of World Business, 37 (1), 40-54.

Kağıtçıbaşı, Ç. (2005). Autonomy and relatedness in cultural context implications for self and family. Journal of Cross-Cultural Psychology, 36(4), 403-422.

Kağıtçıbaşı, Ç. (2013). Benlik, aileveinsangelişimi, kültürelpsikoloji. İstanbul:KoçÜniversitesiYayınları.

Kasser, T., \&Ahuvia, A. (2002). Materialistic values and well-being in business students. European Journal of Social Psychology, 32 (1), 137-146. 
Kasser, T., \& Ryan, R. M. (1993). A dark side of the American dream: Correlates of financial success as a central life aspiration. Journal of Personality and Social Psychology, 65 (2), 410-422.

Kasser, T., \& Ryan, R. M. (1996). Further examining the American dream: Differential correlates of intrinsic and extrinsic goals. Personality and Social Psychology Bulletin, 22 (3), 280-287.

Keyes, C. L., \&Annas, J. (2009). Feeling good and functioning well: Distinctive concepts in ancient philosophy and contemporary science. The Journal of Positive Psychology, 4 (3), 197-201.

Keyman, E. F. (2010). Modernization, globalization and democratization in Turkey: the AKP experience and its limits. Constellations, 17(2), 312-327.

Köker,

S.

(1991).

"Normal

veSorunluErgenlerin YaşamDoyumuDüzeylerininKarşılaştırılması".

Yayımlanmamış YüksekLisansTezi, Ankara: Ankara Üniversitesi.

Kuşdil, M. E., \&Şimşek, S. (2008). The importance of values in predicting Turkish youth's opinions about the European Union in light of the Copenhagen Political Criteria. International Journal of Psychology, 43 (6), 988-996.

Kuşdil, M. E., \&Kağıtçıbaşı, Ç. (2000). Türköğretmenlerindeğeryönelimlerive Schwartz DeğerKuramı. TürkPsikolojiDergisi, 15(45), 59-76.

Lu, L., \& Gilmour, R. (2006). Individual-oriented and socially oriented cultural conceptions of subjective well-being: Conceptual analysis and scale development. Asian Journal of Social Psychology, 9(1), 36-49.

Mardin, Ş. (1973). Center-periphery relations: A key to Turkish politics?.Daedalus, 169-190.

Myers, D. G., \&Diener, E. (1995). Who is happy?.Psychological Science, 6 (1), 10-19.

Oishi, S., Diener, E., Suh, E., \& Lucas, R. E. (1999). Value as a moderator in subjective well-being. Journal of Personality, 67 (1), 157-184.

Öniş, Z. (2004). TurgutÖzal and his economic legacy: Turkish neo-liberalism in critical perspective. Middle Eastern Studies, 40 (4), 113-134.

Örücü, E., Asunakutlu, T. \&Öncü, G. (2003).Çalışanlarınişdeğerlerivebiruygulama. İktisat, İsletmeveFinans: Inceleme-Araştırma, 18 (209), 3-17.

Öztürk, A., \&Mutlu, T. (2010). The relationship between attachment style, subjective well-being, happiness and social anxiety among university students. Procedia-Social and Behavioral Sciences, 9, 1772-1776.

Roccas, S., Sagiv, L., Schwartz, S. H., \&Knafo, A. (2002). The big five personality factors and personal values. Personality and Social Psychology Bulletin, 28(6), 789-801.

Ryan, R. M., \&Deci, E. L. (2000). Self-determination theory and the facilitation of intrinsic 
motivation, social development, and well-being. American Psychologist, 55 (1), 68-78.

Ryan, R. M., \&Deci, E. L. (2001). On happiness and human potentials: A review of research on hedonic and eudaimonic well-being. Annual Review of Psychology, 52 (1), 141-166.

Ryan, R. M., Sheldon, K. M., Kasser, T., \&Deci, E. L. (1996). All goals are not created equal: An organismic perspective on the nature of goals and their regulation. In Gollwitzer, Peter M.,Bargh, John A. (Eds.), The psychology of action: Linking cognition and motivation to behavior. (pp. 7-26). New York, NY, US: Guilford Press.

Ryff, C. D., \& Singer, B. (1998). The contours of positive human health. Psychological Inquiry, 9(1), 1-28.

Sagiv, L., \& Schwartz, S. H. (2000). Value priorities and subjective well-being: Direct relations and congruity effects. European Journal of Social Psychology, 30 (2), 177-198.

Sargut, A.S. (2001). Kültürlerarasıfarklılaşmaveyönetim. Ankara: İmgeYayınevi.

Sargut,

A.S.

(2003).

KurumsalAlanlardakiÖrgütYapılarınınOluşmasındaveEkonomikİşlemlerinYürütülmesindeGü veninRolü, in F.Erdem (Ed.) SosyalBilimlerdeGüven, (pp.89-124), Ankara: VadiYayınları.

Schwartz, S. H. (1992). Universals in the content and structure of values: Theoretical advances and empirical tests in 20 countries. Advances in Experimental Social Psychology, $25(1), 1-65$.

Suh, E. M., Diener, E. D., \&Updegraff, J. A. (2008). From culture to priming conditions self-construal influences on life satisfaction judgments. Journal of Cross-Cultural Psychology, 39 (1), 3-15.

Suh, E., Diener, E., Oishi, S., \&Triandis, H. C. (1998). The shifting basis of life satisfaction judgments across cultures: Emotions versus norms. Journal of Personality and Social Psychology, 74 (2), 482-493.

Toprak, B. \&Çarkoğlu, A., (2006). Türkiye'de din toplumvesiyaset. Istanbul: TESEV.

Vansteenkiste, M., Lens, W., \&Deci, E. L. (2006). Intrinsic versus extrinsic goal contents in self-determination theory: Another look at the quality of academic motivation. Educational Psychologist, 41 (1), 19-31.

Watson, D., Clark, L. A., \&Tellegen, A. (1988). Development and validation of brief measures of positive and negative affect: the PANAS scales. Journal of Personality and Social Psychology, 54(6), 1063-1070.

Williams, M. (2001). In whom we trust: Group membership as an affective context for trust development. Academy of Management Review, 26(3), 377-396.

Yalçın, İ., \&Malkoç, A. (2014). The relationship between meaning in life and subjective well-being: Forgiveness and hope as mediators. Journal of Happiness Studies, June, 1-15.

Yeşilada, B. A., \&Noordijk, P. (2010). Changing values in Turkey: Religiosity and tolerance 


\section{Macrothink \\ International Journal of Human Resource Studies \\ ISSN 2162-3058 \\ 2014, Vol. 4, No. 4}

in comparative perspective. Turkish Studies, 11(1), 9-27.

Yetim, U. (1993). Life satisfaction: A study based on the organization of personal projects.

Social Indicators Research, 29, 277-289. 